\title{
Introduction: Double Intentionality
}

\author{
Michela Summa $^{1} \cdot$ Martin Klein $^{1} \cdot$ Philipp Schmidt $^{1}$
}

Accepted: 20 November 2021 / Published online: 14 December 2021

(c) The Author(s) 2021

Consider the following scenarios:

- You are in a lab, and you see various tools you don't recognize. Your friend who is studying biology tells you that what you see is a common glass burette; you look around and wonder whether the concept 'glass burette' might apply to some other object you see in the room.

- Tired from work, you drive home, reminiscing about the sunset you saw as you walked along the beach during your vacation last summer.

- You plan to bake a cake for the party you are hosting tomorrow, and you think about what you need to buy and when you can do your grocery shopping.

- You react with fear when you meet a dog, but you then feel relieved because in fact it is only a puppy.

- You go hiking with a friend and you talk about how much you are enjoying this time together after a long period of isolation.

These are experiences that, in their own ways, are directed at something or are about something. They are thus examples of different intentional acts. Typically, intentionality is described as a one-way relation between acts and their objects. On a closer look, however, we can see that the intentional relation in these examples is more complex than a simple one-way being-directed-at-an-object. In all of them, there are two intentional directions that can be recognized. For example, when you see a glass burette you are certainly intentionally directed at a glass burette. But when you consider how, on the basis of this perceptual act, you can intentionally turn to the concept that determines the object of this

Michela Summa

michela.summa@uni-wuerzburg.de

Martin Klein

martin.klein@uni-wuerzburg.de

Philipp Schmidt

philipp.schmidt@uni-wuerzburg.de

1 Universität Würzburg, Institut für Philosophie,

Residenzplatz 2, 97070 Würzburg, Germany act as a glass burette, a two-way directedness comes to the fore: besides the intention directed at the perceived object, there is also an intention directed at the concept. In the case of memory, what you remember is certainly the sunset, but you are also aware that it was you who had that experience in the past, and the way you remember the sunset now is affected by how you previously experienced it; in other words, your memory is directed not only at the sunset, but also, implicitly, at how you experienced the sunset last summer and how it appeared to you then. While planning to bake a cake and then while baking it, your thoughts are primarily directed at the cake as the outcome and end of your action, but you are also implicitly intending the individual steps you have to take in order to arrive at a (hopefully satisfactory) result. Double intentional relations are also implied in certain emotional experiences, such as the feeling of appropriateness or inappropriateness of an emotion (e.g., after noticing that the dog you were afraid of is only a puppy, for most people it feels wrong to keep being afraid of it), or sentiments of approbation and blame: in all these cases, the emotion is intentionally directed toward another emotion, which is itself intentionally directed an an object. And finally, shared experiences also have a complex intentional structure: when you discuss with someone the shared experience of hiking together, you are intending the experience (in this case, the hiking), but you are intending it with the underlying awareness of the hiking experience not just as singularly yours, but also as a shared experience-thus as yours in the plural.

As these examples show, a simple view of intentionality as one-way object-directedness is inadequate to describe many intentional experiences. A deeper understanding of the complex structures of different kinds of intentional experience is required. The concept of intentionality is assigned a central role in phenomenology and in the philosophy of mind. But it can only play such a role if it helps elucidate the complexities found in concrete experiences of the world, of ourselves, and of others.

The aim of this special issue is to address different topo $i$ of complex intentional structures and to elaborate on concepts that allow us to properly describe and understand these 
complexities by focusing on how two intentions can be connected and interwoven in a single act. While references to double intentionality are to be found in both classic and contemporary work in phenomenology and the philosophy of mind, there is still a need for a closer analysis of the structures of double intentionality and of the acts displaying a double intentionality.

It is noteworthy that, when they mention double intentionality, some authors in phenomenology and more generally in twentieth-century philosophy seem to have medieval approaches to intentionality in mind, or at the very least we can say that there are references to distinctions that are characteristic of medieval theories of intentionality, such as those between first and second intentions, between intentio prima and secunda, and between intentio recta and obliqua. ${ }^{1}$ However, these references are usually not systematically developed, and so questions arise as to whether and how research on intentionality might benefit from a joint reassessment of contemporary and medieval work on double intentionality.

These references are not the only motive for focusing the inquiry into double intentionality on contemporary philosophy of mind, phenomenology, and medieval philosophy. Underlying this orientation is the hypothesis that the results obtained in these different traditions of thought on the structures of intentionality in general, and of double intentionality in particular, can be mutually enlightening in several respects. More specifically, the articles in this volume show that contemporary and medieval theories of intentionality can fruitfully contribute to research on double intentionality regarding at least three issues: (i) the relation between object intentionality and self-experience, both as immediate self-awareness and as memory-based self-consciousness; (ii) the relation between intentions directed toward objects and toward different kinds of concept; and (iii) the intentional relations involved in both action and emotions.

In this introductory essay, after presenting in the first section some crucial aspects of how intentionality is understood across the medieval and the Brentanian-phenomenological traditions, we will devote the three subsequent sections to each of the just-mentioned issues. While the plurality and complexity of the various theoretical approaches prevent us from making an exhaustive survey of all debates on the topic of double intentionality, we aim to situate the results of the individual papers published in this issue within a broader discussion, in order to provide a more encompassing view of the variety of phenomena that display a double intentional structure.

\footnotetext{
${ }^{1}$ See, for instance, Brentano (1995, pp. 78-79, 211-212), Hartmann (1985, pp. 46-47), Recanati (2000), Sowa (2007), and Moran (2013).
}

\section{Intentionality Across Traditions}

The discussion of double intentionality presupposes a specific understanding of the concept of intentionality. The term is broadly understood in contemporary philosophy as referring to the distinctive feature of mental acts: their directedness at something or their aboutness (see Brentano 1995, pp. 59 f.; Crane 1998; Jacob 2014; Siewert 2017; Müller and Summa 2018). Such an understanding of intentionality is generally associated with Franz Brentano, whose account of the mind, controversially discussed, deeply influenced research in phenomenology and the philosophy of mind, and contributed to the establishment of psychology as a science. However, Brentano does not use the general concept of intentionality in his Psychology from an Empirical Standpoint as he does in some manuscripts, but speaks rather of the "intentional inexistence" (Brentano 1995, p. 68) of an object in the corresponding act. The prefix 'in' in the term 'inexistence' should be understood as designating a partwhole relation, according to which "[e]very mental phenomenon includes something as object within itself" (Brentano 1995, p. 68).

Brentano elaborates on the concept of intentional inexistence by drawing on the medieval discussions of intentio (Marras 1977; Runggaldier 1989; Jacquette 2004; Perler 2004; Moran 2013; Mc Donnell 2015; Müller and Summa 2018). His understanding of intentional inexistence, however, is narrower than the medieval and scholastic understanding of intentio. In fact, for medieval philosophers, the term intentio generally denotes a tendency (in aliquid/aliud tendere $),{ }^{2}$ the striving of something for something (else), or the directedness of something toward something else. The concept of intentio thus alternatively applies to everything exhibiting a tendency, to the means by which tendency comes about, and to what is intended by the tendency. On such a broad understanding, intentio is not exclusive to mental states and does not define their mark (King 2010; Klima 2013, 2015; Zupko 2015); rather, according to the medieval thinkers, every entity that tends toward something else can be said to have an intention. It is not only acts of willing, understanding and perceptions, but also sensible and intelligibile species (i.e., those representational devices

\footnotetext{
2 Aquinas claims that the term intention is properly applied to appetitions or strivings and only in a figurative sense to cognitions; see ST I-II, q. 12, art. 1 (Thomas Aquinas 1891, p. 94). Hervaeus Natalis claims in one passage that there are intentions of willing and understanding but he leaves it at this without dealing with the will in the remainder of the text; see DSI, q. 1, art. 1 (Hervaeus Natalis 2008, p. 332). With explicit reference to Avicenna's conception of logic (see the next section), Henry of Ghent interprets intentions as concepts and their referentiality; see Quodl. V, q. 6 (Henry of Ghent 1518, fol. 161rL).
} 
that emitted from intelligible and perceptible objects to cognizers make cognition possible) that are called intentions. Even natural entities can be conceived as intentional: for instance, fire is typically described as having the tendency to burn anything combustible, and it is thus intentional in this broad sense. This extended scope of the term intentio derives from the transmission of Arabic texts into the Latin-speaking intellectual community in the twelfth century, specifically from a variety of Arabic terms that could be rendered in English as meaning, concept, or sense, but also as respect, purpose, which were all translated into Latin as intentio. ${ }^{3}$

Brentano's claim that "intentional inexistence" is the mark of the mental, then, takes up only one specific meaning among the variety of meanings the concept of intentio had for medieval thinkers. In support of Brentano's interpretation, however, it should be noted that he himself was aware of this restriction, as testified by the fact that in his Psychology from an Empirical Standpoint he does not use the medieval term intentio or the German Intention, but refers only to the medieval notion of an intra-mental object or content at which the mind is directed. ${ }^{4}$ This is precisely what medieval thinkers consider to be the mark of the mental (de Rijk 2005, pp. 27-29; Amerini 2011b).

This special issue concentrates only on intentionality as a characteristic feature of mental acts. With this focus in mind, a constitutive feature of the medieval understanding of intentionality helps illuminate the framework within which a theory of double intentionality should be embedded and sheds light on both Brentano's concept of intentionality and the phenomenological concept of intentionality: that is, intentionality is a relation.

The idea that 'intentionality' denotes a relation can already be seen in the first extensive treatises on intentions written in the fourteenth century. Notably, Hervaeus Natalis (d. 1323), in his treatise On Second Intentions-which has been called the "baptismal certificate of intentionality" (Knebel 2009) - uses intentionalitas describe the relation that an object, in being cognized, has with the cognizing subject (Doyle 2009)..$^{5}$ In a similar vein, Brentano uses the general term Intentionalität in some manuscripts from the 1870s that discuss various kinds of relation. Accordingly,

\footnotetext{
3 The conceptual history of intentio is yet to be written for this stage of transmission from Arabic into Latin. An important source is recently the entry for intentio in the Arabic and Latin Glossary (Hasse 2021).

${ }^{4}$ See, notably, the annotation in Brentano (1995, pp. 68, 140).

${ }^{5}$ For an extensive discussion of Natalis's theory of intentionality, with particular reference to the distinction between first and second intentions, see Amerini's paper in this special issue. Brentano knew of Hervaeus and the existence of his treatise (Brentano 1867, p. 570), if only through contemporary compendia on the history of philosophy (Hedwig 1978, pp. 73-74; Werle 1982).
}

applying 'intentionality' to the description of the mental implies conceiving of mental activities themselves as essentially relational (Rollinger 2010, p. 24; 2011, p. 263; Taieb 2018). Relationality is also the main feature of intentionality according to Husserl's phenomenology, and this characterization is maintained in post-Husserlian phenomenology. In fact, phenomenology builds on the idea of a necessary correlation between subject and object as well as between the subject and the world as the horizon of meaningful givenness (e.g., Husserl 1960; 1970, pp. 151-152, 159-160; 1983; pp. 211-212).

Against the background of a shared understanding of intentionality as a relation, different approaches to the nature of such a relation have been developed. One of the main issues marking the distinction between different theories of intentionality concerns representationalism. To state it briefly, representationalist accounts of the mind contend that intentional acts are directed at immanent objects or contents, which function as mental representations of external objects, whereas non-representationalist accounts hold that acts directly intend what medieval philosophers call extramental objects and phenomenologists call transcendent objects. In order to understand the importance of this divide, we must take a closer look at the concepts of intentional object content, and act.

Objectum, as a technical term for what is presented to the mind, is a concept that evolved in the late thirteenth century (see Dewan 1981; Knebel 1998; Kobusch 1987). Within medieval debates, it is generally assumed that if an object is to be cognized, it cannot be entirely different from that by which it is cognized, that is, the mind. Accordingly, the object and the cognizing mind, on the medieval standard view, must be to a certain extent homogeneous and have some affinity to each other. If they were completely heterogeneous, the argument goes, it would be impossible to explain how the mind could have access to what would be, formally speaking, a completely separate ontological realm, namely, the world of things. The form of the cognized object must therefore be homogeneous with the mind; it is in precisely this sense that we should also understand the claim that the intended object is 'in' the mind. Once this inner representation is postulated, however, the question as to the relation between the object represented in the mind and the extramental thing arises and often remains unsolved (Perler 2004; de Rijk 2005; Anisi et al. 2020).

This representationalist view of the medieval scholastics, despite any differences in the broader account of mind and cognition, which are related to the cultural and philosophical milieu in which it was developed, is largely shared by Brentano. Drawing from Aristotle's theory of perception and from the scholastics, but within the framework of a psychology concentrating on mental states rather than positing the soul as an immaterial substance, Brentano understands 
intentional inexistence literally. The sound one hears, for instance, is included within one's act of hearing, the figure one sees is included as a part of one's act of seeing, etc. Brentano assumes-at least in Psychology from an Empirical Standpoint - that the intentional relation is actually a relation between mental states and an immanent object (Simons 1995). Against this background, cognition can only rely on inner representation, in which further mental states of judging, desiring, and feeling are grounded.

While recognizing the debt to their master, Husserl and other Brentano scholars like Meinong emphasize that the account in the Psychology is based on a somewhat misleading conflation of the concepts of content and object. Such ambiguity makes it difficult to understand whether the discussion of intentional inexistence is a psychological claim about the directedness of mental acts, an ontological claim about intramental objects or contents, or a claim about the correlation between a mental state and an object (Schreiber 2021).

Insisting on the need to disambiguate the concepts of content and object, Husserl arrives at a non-representationalist theory of intentionality. Husserl (2001b, pp. 94-95) considers intentionality to be the distinguishing feature not of every mental phenomenon but only of conscious acts, and argues that sensible contents like a sound sensation or a color sensation are not to be conceived of as immanent objects that somehow represent external objects. Rather, they are non-intentional but still conscious components of acts, and need to be apprehended as objectual features. Sensible contents-which Husserl also calls "real" (reell) or "descriptive"-are to be distinguished from transcendent or extramental objects: while the former are parts of the act, the latter are not. On this account, it would be wrong to say that cognition of extramental objects requires a mental representation or a mental image that is homogeneous with the mind (Husserl 2001b, pp. 125-126, 335-336). Rather than postulating inner representations, Husserl argues that the experience and cognition of unitary transcendent objects is possible thanks to the mind's capacity to synthesize the different modes of appearance of objects-that is, the "matter" of the act, or the intentional content (Husserl 2001b, pp. 112-113) —into a unity. Cognition arises on the basis of such a synthesis of the modes of appearance of the object in connection with the relevant categorial formations that make predication possible. Such a non-representationalist view becomes more and more prominent in post-Husserlian phenomenology, notably in Maurice Merleau-Ponty's (2005) examplary analyses of perception.

The distinction between representationalist and nonrepresentationalist accounts of the mind impinges on the discussion of double intentionality. While the question for representationalist approaches is to clarify how the structure of representation could entail two different intentional directions-and thus possibly a duplication of the intentional object-non-representationalist views do not have this problem but are confronted with the need to develop descriptions that would be appropriate for the complex articulation of non-representational consciousness.

\section{Object-Awareness and Self-Awareness: Consciousness and Memory}

One area of research in which the inquiry into double intentionality has had particular resonance is the relation between consciousness of something and self-consciousness broadly construed. Perceiving, desiring, thinking about, and having a feeling about an object $x$ are intentional acts in that they are directed at $x$ or entail the awareness of $x$-but not only $x$, for when performing an intentional act one is also aware of this very act. In perceiving a tree, one is not only intentionally directed at the tree: one is also aware in a specific way of one's own perceiving. Several medieval thinkers, Brentano, Husserl, and many post-Husserlian phenomenologists all share this basic assumption and are interested in investigating the specific features of object-awareness and selfawareness, as well as how they are related.

\subsection{Consciousness and Self-Consciousness}

What is self-awareness, and how does it relate to objectawareness? With regard to this question, the main divide in the philosophy of mind across different traditions can be traced back to the distinction between two-level and onelevel accounts of self-awareness. Two-level accounts contend that self-awareness comes about by means of an act of reflection directed at intentional acts. Accordingly, two levels are involved in the constitution of self-awareness: an intentional act that is directed at an internal or external object, and a reflective, or higher-order intentional act that is directed at the intentional act of the first level. By contrast, one-level accounts contend that self-awareness and object-awareness are integrated in one and the same level of consciousness: when we are intentionally directed at an object $x$, we are aware of both $x$ and the consciousness in which $x$ is given. Proponents of one-level accounts typically also endorse the stronger claim that all intentional consciousness involves self-awareness. The distinction between one-level and twolevel accounts of self-consciousness provides a helpful perspective in comparing the theories of double intentionality in medieval thinkers, Brentano, and the subsequent phenomenological tradition. 


\subsubsection{Medieval Approaches to the Act-Object Relation}

Although the term consciousness was not used by medieval philosophers, ${ }^{6}$ they developed an extensive discussion that touches on precisely the issues mentioned above. They generally put those questions in terms of cognition, which includes sensations, perceptions, and understandings. Sometimes they formulate these questions more specifically in terms of the knowledge that people can have about themselves and their own mental states (Perler and Schierbaum 2014; Klein 2019, pp. 311-337).

Medieval philosophers generally agree that the mind can reflect on its own act. The problem, however, is not so much whether such reflection is possible, but rather whether it is necessary for self-consciousness. Maintaining that selfreflection is necessary for self-consciousness would amount to defending a two-level theory of self-consciousness: at one level we are aware of the object, and at a second level we are aware of our own acts (and inferentially of ourselves). ${ }^{7}$ To be aware of a stone is an act of perceiving the stone, and to be aware of one's own perception of the stone is equally construed as a perception, one of intramentally perceiving one's own act of perceiving the stone (Yrjönsuuri 2007).

There are at least two interconnected problems with such an account, both related to the status of the reflecting act. If we assume that consciousness of acts can be realized only via reflection, then we are faced with this alternative: the act of reflection itself either becomes conscious through a further act of reflection, or it does not become conscious at all. If one endorses the former view, there will be an infinite regress of reflecting acts. Conversely, if one maintains that another reflecting act is not required, one must accept the existence of mental states of which a subject is totally unaware, namely, the ultimate reflecting act.

Regarding the threat of an infinite regress, we can find two paradigmatic solutions in the Middle Ages. The first one is formulated by Thomas Aquinas, who acknowledges the regress but denies that this is a problem. Reflection, in fact, is an activity of the intellect, which is an immaterial human faculty with a distinct ontological status and as such is able to infinitely reflect upon its own acts. ${ }^{8}$ The second solution can be found in the writings of William of Ockham. Ockham acknowledges that the regress is metaphysically

\footnotetext{
${ }^{6}$ It is only in early modern philosophy that the medieval Latin term conscientia comes to designate consciousness; in medieval philosophy conscientia rather means conscience. See Eardley (2021).

${ }^{7}$ Recall that a similar psychological process lies behind the formation of second intentions as described in the previous section: the intellect forms second intentions when it considers first intentional content by reflecting on first intentional acts.

${ }^{8}$ See ST I, q. 87, art. 3, ad 2 (Thomas Aquinas 1889, p. 361b). See also Pasnau (2002, ch. 11), Putallaz (1991), and Cory (2013).
}

conceivable but denies that it is psychologically realizable. Accordingly, it is not a concrete threat: the mind would simply stop reflecting once it has reached a certain number of reflective acts. He argues that it is not the case that the mind is caused necessarily to produce reflective acts. Our seeing a stone does not automatically produce acts of reflection; instead, reflection is something which we voluntarily decide to bring about or not. ${ }^{9}$ On this account, not every act needs to be self-aware; in fact, every mental act that is self-aware is accompanied by one that is not. Ockham's account thus avoids the infinite regress problem, but is confronted with the problem of assuming that there are some mental acts that are entirely unconscious.

Medieval proponents of one-level accounts of self-consciousness tried in various ways to overcome both problems. Peter John Olivi argues against the view that the subject's awareness of its own mental act comes about only through a distinct reflective act. ${ }^{10}$ Though he does not deny that it is possible for the mind to elicit a distinct reflective mental act which is directed both at an act and at the object of that act, he thinks that a subject must already be implicitly aware of the direct act itself, without a further mental episode of explicit reflection. Accordingly, Olivi has been interpreted as a proponent of a pre-reflective self-awareness (BrowerToland 2013). To make pre-reflective self-awareness plausible, he suggests resorting to a metaphor of sense perception: in having mental states, the soul immediately feels them, similar to how the sense of touch immediately feels heat or the like. The soul cannot have mental acts without immediately experiencing itself. ${ }^{11}$

One generation after Olivi, further elaborations of the one-level account are to be found in the writings of Walter Chatton and Durand of St. Pourçain. As Charles Girard shows in his contribution to this issue, Chatton takes prereflective self-awareness to be a genuine form of reception that is exclusive to "a living subject" that "receives its own act." 12 Durand on the other hand argues that pre-reflective self-awareness is intrinsic to the act that is directed at the object itself: it is "in relation to the principal object and through the same act" that "I cognize a rose and that I cognize that I cognize a rose." ${ }^{\prime 3}$ A mental act, according to Durand, is directed at the principal object and at the same time at itself; on Girard's reading, this implies that the

\footnotetext{
${ }_{9}$ See Quodl. I, q. 14 and II, q. 12 (William of Ockham 1980, pp. 80 and 166-167). See also Brower-Toland $(2012,2014)$ and Michon (2007).

${ }^{10}$ In Sent. II, q. 79 (Peter John Olivi 1926, p. 164), trans. BrowerToland (2013, p. 157).

11 In Sent. II, q. 76 (Peter John Olivi 1926, p. 146).

12 Rep. et Lect. super Sent., prol. q. 2, art. 5 (Walter Chatton 1989, p. 121).

13 De lib. arb., q. 3 (Durand of St. Pourçain 1962, p. 497).
} 
act is a secondary object of cognition (see also Hartman 2021). As Girard further suggests, Chatton's and Durand's accounts can be seen as precursors of Brentano's account of self-consciousness.

\subsubsection{Self-Consciousness and Object-Directedness in Brentano}

Although it has been argued that Brentano's theory ultimately supports a higher-order theory of self-consciousness (Rosenthal 1997), he is now usually read as proposing a one-level account of consciousness and self-consciousness (see Thomasson 2002; Zahavi 2004; Frank 2015). In fact, Brentano claims that mental acts are structurally characterized by a double intentional relation, and thus that there is no need to posit a further act of reflection: they are directed at their objects as primary objects, and at themselves as secondary objects. Brentano also calls this self-directedness "accompanying" or "incidental" consciousness, thereby indicating that it is not to be understood as a higher-order reflective act. For instance, when we hear a sound, "[w]e can say that the sound is the primary object of the act of hearing, and that the act of hearing itself is the secondary object" (Brentano 1995, p. 98). The act of hearing is directed "toward the sound in the most proper sense of the term, and because of this it seems to apprehend itself incidentally and as something additional" (Brentano 1995, p. 98). 'Incidentally' (nebenbei or en parergo in the Greek text of Aristotle, on whom Brentano draws) does not mean here that this self-consciousness may or may not be occurring, but rather that being conscious of the hearing is dependent on the act of hearing. ${ }^{14}$ But whenever we have an intentional experience directed at something, like hearing a sound, the accompanying self-consciousness is also given. This has two important consequences. First, the idea of an unconscious consciousness or act is ruled out. Secondly - and this marks the difference of Brentano's view from higher-order theories of self-consciousness-incidental self-consciousness is not to be confused with inner "observation" (Beobachtung): while inner observation is indeed a further act, which may or may not occur (Brentano 1995, p. 22), the performance of every act is necessarily accompanied by incidental self-consciousness.

Brentano's view has been widely discussed in the literature. ${ }^{15}$ In particular, it has been shown that his one-level

\footnotetext{
14 See Brentano (1995, p. 215); cf. Aristotle (1984) Met. XII.9, 1074b35: "Evidently, knowledge and perception and opinion and understanding have always something else as their object, and themselves only en parergo" (trans. Ross).

15 E.g., Hossack (2002), Thomasson (2002), Jacquette (2004), Zahavi (2004), Textor (2006), Kriegel (2016), Soldati (2017), and Marchesi (2019)
}

theory avoids some of the problems faced by higher-order theories of self-consciousness, notably, the threat of infinite regress (Brentano 1995, pp. 93-94). There is, however, another concern with Brentano's account of the double intentionality of object-consciousness and self-consciousness, namely, the problem of the duplication of the primary object. This problem is discussed in Andrea Marchesi's contribution to this volume: if the sound is the primary object or content of the act of hearing, then it should also be the indirect content of the self-consciousness of the act of hearing. Are we then to admit that there is a duplication of the intentional object? And is this theoretically plausible? Marchesi claims that these problems are eliminated at the root if we more rigorously consider acts as mereological units, and he investigates the relations between the act as a whole and its parts.

\subsubsection{Self-Consciousness as Non-Objectual Consciousness in Phenomenology}

Like Brentano, Husserl too defends a one-level account of self-awareness; unlike Brentano, he does not conceive of self-awareness as a specific kind of object-awareness. Husserl's position emerges precisely from his understanding of double intentionality (doppelte Intentionalität) and self-awareness in relation to the phenomenology of timeconsciousness. The core of Husserl's mature view is that the stream of consciousness appears to itself together with its experiential contents (Husserl 1991, pp. 77-78, 370-371, 379-360). When perceiving a temporal object-for example, when hearing a melody_one's awareness of one's own act of hearing is not to be understood as an object-awareness, but rather as the immediate and non-reflective awareness of an ongoing temporal process in which both the melody and the acts are constituted.

Husserl still defends a one-level account of self-consciousness, without however claiming that we are aware of our own acts as secondary objects. He suggests that in every act, the consciousness of the object involves a pre-reflective and non-objectual awareness of oneself as experiencing the object (see Bernet 1985; Zahavi 1998, 1999, 2002; Kortooms 2002). On this understanding, we can still speak of double intentionality, but we also need to distinguish between an objectual and a non-objectual intentionality; in his analyses of time-consciousness, Husserl calls them transverse intentionality (Querintentionalität) and longitudinal intentionality (Längsintentionalität) respectively (Husserl 1991, pp. 84-85, 379-380). ${ }^{16}$ While transverse intentionality is directed at the temporal object, longitudinal intentionality

\footnotetext{
16 See also Bernet (1985), Zahavi (1999, pp. 74-75), De Warren (2009, pp. 172-173), and Summa (2014, pp. 111-112).
} 
is directed at the experiential process or flow. The two intentionalities are considered to be "inseparably united" and to require one another "like the two sides of the same thing" (Husserl 1991, p. 87). According to this view, the very same flow of temporal consciousness that intentionally constitutes temporal objects also constitutes itself as temporal; the awareness of the object is accompanied by self-awareness, which "does not require a second flow" but "constitutes itself as a phenomenon in itself" (Husserl 1991, p. 88).

Husserl's notion of a pre-reflective and sui generis nonobjectual self-awareness can be seen as a "silent consensus" (Wiesing 2020, p. 55) among all the phenomenologists that followed Husserl, although thinkers such as Gurwitsch (1966), Henry (1973), Sartre (1956, 2004), and MerleauPonty (2005) developed their own phenomenological accounts of self-awareness.

\subsection{Memory}

The connection between the temporality of experience and the relation between consciousness and self-consciousness highlight how important it is on the one hand to consider intentional life as a process, and on the other hand to distinguish the different levels of the constitution of self-consciousness. This becomes clearer if we reassess what has been said so far about double intentionality and self-consciousness in relation with the double intentionality that is specific to acts of memory.

\subsubsection{Memory and Self-Consciousness in Medieval Philosophy}

Medieval philosophers consider memory against the backdrop of two traditions: on the one hand, that of Aristotle and Arabic thinkers, according to whom memory concerns the reactivation of sensory representations of an object experienced in the past which have been stored in the inner sense; on the other hand, that of Augustine, who also discusses purely intellectual memory. Both traditions emphasize that memory is closely linked with a person's self-awareness. When Augustine says that in the context of learning, "I also remember that I have remembered" ${ }^{17}$ he is claiming that the object of our memory is not only the previously acquired understanding of something but also the fact that we have acquired knowledge and the manner in which we have done so. Thus, when a person remembers something, she is not only aware of a past object but also of herself as the one who once experienced something and the one who is now reactivating those past experiences (Müller 2015, p. 95). Similarly, Aristotle (1984) remarks that one cannot

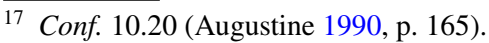

remember without being aware that one remembers $(D e$ mem., 452b26-27; cf. Nikulin 2015, p. 64).

Both traditions raise the problem of what the precise content and structure of memory is. For instance, when we remember a sunset we saw while on holiday last year, do we remember the sunset which we saw or do we rather remember ourselves experiencing it? Thomas Aquinas, following the first path, wants to explain how it is possible that we can have access to objects of past cognitions. Regarding sensory memory, he claims that we reactivate representations that were once acquired from an object and stored in (the organ of) the inner sense. However, we do not make them into the object of our recollective act; rather, previously acquired representations serve as vehicles through which we re-present the object we have seen in the past (Perler 2020, pp. 247-249).

To highlight the past mental state rather than its object as what is primarily remembered implies a special focus on the relation between memory and self-awareness. We can see this more clearly in John Duns Scotus who, one generation after Aquinas, elaborates on the problem of how the intellect can think of past mental acts, that is, how memory is primarily of our acts rather than of their object. Memory is possible of every cognition that was accompanied by what Scotus calls an "intuitive act", through which one was originally aware of the cognition. This accompanying act is stored in the intellect alone and serves as a cognitive vehicle for an occurrent act of recollection (recordatio) through which the past act becomes accessible for the subject. Thus, only mental acts that were consciously experienced when they occurred can be recollected, and therefore those recollected acts must be conceived of as ours (Cross 2014, pp. 57-63).

Scotus's inward turn to past experience leads him to conceive of the recollected mental act as what he calls the "proximate object" of memory, and the object of the past cognition as the "remote object". Dominik Perler shows in his contribution to this volume how one generation later, Scotus's confrère William of Ockham took up and further developed Scotus's account of memory as being about two objects. According to Ockham's mature theory of the intentional structure of memory, a person remembers directly her past act—what Ockham calls the "partial object"—and indirectly also the object of this act, called the "complex object". Perler analyzes the cognitive mechanism behind memory and pays special attention to the problem of what it means to remember a past cognitive act-an act which strictly speaking is gone and cannot be brought back by the mind as numerically the same act.

In this respect, Perler shows that an analysis of the structure of acts of recollection only in terms of their objects is not sufficient to account for the intentionality of memory. For how does the mind conceive of re-presented acts or remembered things precisely as past, unlike, say, the current 
imagination of some object? Medieval philosophers handle this problem by saying that past acts and their objects are somehow timestamped (Cory 2012). Again, Augustine seems to play a major role in the background. According to his doctrine of the distentio animae, the soul, in an occurrent mental episode of recollection, stretches itself out to a past moment which it has experienced. This means that the soul must be able to connect its present self with its past existence. In memory, it is not the case that we just remember some past event or object; rather, we intend them as being experienced by us in the past, so that it is me who remembers that $I$ saw a sunset last summer.

\subsubsection{Remembering and Re-Presenting in Brentano and Husserl}

Brentano addresses the topic of the double intentionality of memory in the Appendix to his Psychology from an Empirical Standpoint (Brentano 1995, pp. 214-215). He does so in the context of a more general reassessment of intentions directed at relations rather than at objects. The gist of his argument is that we should not confuse the double intentionality of inner perception (see above, Sect. 2.1) with the double intentionality of inner observation. In the latter, we have a double intentionality not only in the sense of an interweaving of self-awareness and object-awareness (which is something that characterizes all acts), but also in the interplay of direct and indirect intentionality, or of intentio recta and obliqua (Brentano 1995, pp. 219-220; cf. Dewalque 2014). It should be noted that this kind of double intentionality extends beyond recollection and pertains to all acts of re-presentation as well as to all consciousness of relations (Brentano 1995, p. 220). In the case of recollection, when we remember the sunset we experienced last summer on the beach, we have a direct intention toward our past experience of the sunset-like an inner observation of our past experience, in which our past experience is the direct object-and an indirect intention toward the sunset itself. The remembered object is thus an intentional object given modo obliquo, or as mediated by the direct "observation" of our past experience.

In this respect too, Husserl takes up some of Brentano's insights, but also revises the general account. Husserl partly agrees that we need to account for the double intentionality of acts of recollection, as well as other re-presentations such as phantasy, expectation, etc. (see Husserl 1991, p. 55; Marbach 1993; de Warren 2016). However, the recollection of a sunset we saw on the beach last summer cannot be rendered as a present intention directed to our previous act, which itself was directed to the sunset. Instead, Husserl suggests that the double intentionality of re-presentation does not entail any kind of nesting of direct and indirect consciousness. When we remember the sunset, we still intend the sunset as our direct object, but we re-present the sunset in a specific modality, namely, as we experienced it last summer. Our previous experience marks the mode of givenness of the remembered object when we intend it in recollection, without turning it into an indirect object. Thus, our own previous experience is not necessarily the object of explicit or attentive recollection: we can just remember the sunset, and thereby be aware that we were perceiving it at some point in the past. This does not rule out that we could turn our attention to our own previous act of perception and so make it the object of recollection. Only in this latter case the structure would be similar to the one Brentano describes. What Husserl rejects, in other words, is that there is necessarily a mediated relation to the object of recollection-that is, that in order to remember the sunset, it is necessary to make the previous act of perception the object of our recollection.

Accordingly, Husserl's account of the double intentionality of memory is also to be understood in a different way. First, given that double intentionality in general is what temporally qualifies self-awareness, we should consider precisely how this qualification applies to memory as a representation directed at the past. In recollection, as we have seen, we have awareness of an object that is marked, as it were, as having been experienced in the past. Secondly, as to self-awareness, in a present act of recollection we are not only implicitly aware that we are now recollecting (as we are aware of the actual performance of every act); we are also aware that we perceived the object in the past. This is revealed by the double "attitude" we can take toward acts of re-presentation (and specifically of recollection) in phenomenological reflection. Given their simulating character, recollections (like all other re-presentations) allow a double focus: a focus on the present act of recollection, or a focus on the past, plunging into it and living in the re-presented world as if it were actual (Husserl 2005, p. 672). ${ }^{18}$ These two attitudes also amount to two intentions that we can have in our present focusing on our memories, and they can be understood in the light of different kinds of attentional focus.

\section{Intending Objects and Intending Concepts: First and Second Intentions}

Within the theory of knowledge and the theory of meaning, the inquiry into the structures of double intentionality is relevant insofar as it brings to the fore the relation between intending objects and intending concepts. The distinction

\footnotetext{
18 In order to describe this double intentional structure, Husserl (2006, pp. 74-75) refers to a complex account of a double phenomenological reduction, which we cannot here discuss in detail: reduction "to" the recollection and reduction "in" the recollection.
} 
between different kinds of conceptual intentions is at the core of medieval theories of intentionality. Though phenomenology formulates these issues within a different framework, some remarkable convergences concern precisely the double intentionality involved in conceptual cognition and the theory of meaning.

\subsection{Prima Intentio and Secunda Intentio in Medieval Philosophy}

The distinction between prima intentio and secunda intentio originates in medieval theories of meaning. A first intention is a concept such as tree, human being, or cup, while a second intention is a concept derived from first intentions, such as genus, species, or subject. Through these higher-order, or formal concepts, things of first intention are conceived in a certain way: a tree can be conceived of as a species, as part of a genus, or as a part of a proposition.

Like the term intentio, the distinction between intentio prima and intentio secunda goes back to the transmission of Arabic philosophy into the Latin tradition. Avicenna distinguishes between "first intelligible meanings" and "secondary intelligible meanings", translated by Dominicus Gundissalinus as intentiones intellectae primo and intentiones intellectae secundo respectively. ${ }^{19}$ Avicenna makes this distinction in order to clarify the proper subject matter of logic: logic is concerned not with real entities such as dogs and their properties, but rather with concepts and their properties. Concepts get these properties because the mind uses them in various ways by, for instance, classifying them or connecting them to propositions (Street and Germann 2013).

The distinction between first and second intentions prompted Latin authors of the Middle Ages to discuss problems of epistemology, psychology, and logic in the broad sense. What is the relation between first and second intentions and the thing of which they are intentions? What are the cognitive structures that underlie the formation of first and second intentions on the basis of our sensory experience of real things?

With a few exceptions, medieval authors tend to agree in considering the formation of concepts an operation of the intellect. Unlike the senses, which work through bodily organs and can only perceive particulars, the intellect is an immaterial faculty and yields general knowledge (Klein 2019). Such general knowledge presupposes the capacity to abstract from the sensory content that is received by the

\footnotetext{
19 See, Kitâb al-Shifâ', al-Ilâhiyyât [Metaphysics] I, cap. 2 (Avicenna 2005, p. 7). See also Kitâb al-Shifâ', al-Madkhal [Isagoge] (Avicenna 1952, p. 15). Engl. trans. in Street and Germann (2013). A similar distinction can be already found in al-Farabi (Gyekye 1971; Oschman 2018).
}

faculty of imagination (in the form of phantasms) and ultimately to form a concept that represents particulars in a general way: this human being as an instance of the concept human being or this red as an instance of the concept red. Some authors, such as Thomas Aquinas, further emphasize that when constructing these concepts, intellectual thinking is always processed in association with phantasms. Especially when a concept is applied to particulars, the intellect is said to "reflect" on the phantasm from which the concept is abstracted (Menn 2012, pp. 65-67; Cory 2013). According to Aquinas, then, the intellect is dependent on the phantasmata in two ways. First, cognition does not rely on general concepts alone, for instance human being; rather, when we attribute to human beings the property of being mortal, we need to imagine a particular human being, such as Socrates. In this sense, in understanding, the intellect works together with the imagination. Secondly, we cognize particulars only through phantasms associated with the concept; for instance, when we point to Socrates and say that he is currently sitting. By itself, the intellect is not capable of recognizing singular things; therefore, it must resort to the phantasmata that represent singular things (conversio ad phantasmata).

On the basis of the acquired concepts, or first intentions of things, such as human being, the mind can build further concepts. These are second intentions; for example, the mind can recognize that there are different ways of conceptualizing things, such as living being, animal, and human being. Recognizing these different kinds of conceptualizations, the mind forms classificatory concepts, such as species and genus. Furthermore, the mind can investigate the role of concepts in propositions and thus form the concepts subject and predicate. A controversial issue-notably discussed by Thomas Aquinas, Radulphus Brito, and Hervaeus Natalis-is whether second intentions are constituted only by comparing extramental things with each other, or whether an intramental comparison of the corresponding concepts is required. If the former is the case, then the intellect depends on the work of the imagination, since without phantasms it would not be able to compare individuals. If the latter is the case, then forming second intentions involves some sort of mental reflection through which the mind refers to itself. In both cases, second intentions are grounded in first intentions.

Another point of debate is whether first and second intentions mean only the concepts of things or also the things themselves. This controversy stems from the ambiguity of the term intentio, which some authors use only for concepts, and others also use for the things of which we have concepts, precisely to the extent that we have concepts of them. Authors endorsing the latter view typically conceive of intentions as a matter of correlation between things and our understandings of them (Pinborg 1974; Pini 2002, ch. 2 and 3; de Rijk 2005; Amerini 2011a). 
An important author who defends the claim that first and second intentions should be understood in connection with the things to which concepts refer is Hervaeus Natalis. Hervaeus contends that a mental act forming a concept directed at an extramental thing is a necessary but not sufficient condition for the thing to be cognized. If the mind's intentionits tending toward something-does not conform with that at which it is directed, cognition remains empty. There is a further necessary formal requirement for the realization of cognition, consisting in the backward relation from an object to the mental act. But how does this relation come about if not through an act of cognition? Fabrizio Amerini's contribution to this special issue focuses on how Hervaeus, elaborating on Thomas Aquinas's account of double intentions, understands this requirement in a non-circular way. Both Hervaeus and Aquinas also emphasize the foundational relations between first and second intentions: both first and second intentions are ultimately grounded in real things, and as Amerini shows, second intentions, which are based on the comparison of the things understood through first intentions, are also founded on first intentions.

\subsection{The Phenomenology of Intentions Directed at Objects and at Concepts}

That Brentano was at least indirectly familiar with the distinction between first and second intentions can be assumed on the basis of his education, which was influenced by nineteenth-century neo-scholasticism (Cesalli and Taieb 2018; Binder 2019, pp. 36-64). In his contribution to this volume, Hamid Taieb shows that in hitherto unpublished manuscripts, Brentano used the medieval distinction between first and second intention to clarify the relations between an object, its presentation, and the content of that presentation. Taieb shows the extent to which Brentano's conception undermines our cognitive access to extramental reality. Furthermore, he shows that Brentano's conception of first and second intentions is similar to medieval accounts according to which first intentions designate what is primarily conceived - that is, things themselves - whereas second intentions are derivative modes of conceiving those things.

Husserl's texts, by contrast, do not suggest that he was familiar with the complex medieval debates about first and second intentions. However, the phenomenological analyses of concept formation and idealization display some significant convergences with the medieval discussions. Simplifying a rather complex theory ${ }^{20}$ _involving discussions of material and formal ontology, as well as formal apophantics and the theory of meaning - we can say that a

${ }^{20}$ See, e.g., Jansen (2017), Lohmar (1998, 2005, 2008), De Santis (2021), and Sowa $(2007,2021)$. double intention characterizes acts that are responsible for (i) the formation of general concepts and (ii) the formation of formal concepts. Husserl emphasizes the importance of not conflating the intentional processes underlying generalization and formalization (Husserl 1969, pp. 48-49; 1983, pp. 26-27), and investigates the structures of double intentionality pertaining to both processes. In both cases, what we intend is a category - a material one in generalization and a formal one in formalization. Also, a categorial intuition, that is, the act through which categories are cognized, has the structure of a double intention: the intention of the complex act directed at the category is founded on the intention of a straightforward act directed at individuals (Husserl 2001b, pp. 271-272).

(i) Generalization is the process through which material concepts or categories, also called "species" in the Logical Investigations, are formed. An example of a material concept is red. The intention directed at species can only be founded on the intention directed at singular objects. Thus, for example, we can intend a red object in a straightforward act such as a perception, and thereby mean precisely this individual red object; but we can also intend the redness of the object, that is to say, the red in specie, "the single identical Red" (Husserl 2001a, p. 237). This is a "novel conscious manner" - or an intention grounded in the intention directed at the individual- "through which precisely the Species, and not the individual, becomes our object" (Husserl 2001a, p. 237). Starting from the apprehension of this red in specie, we can proceed to further levels of generalizing intentions and build further material concepts, such as carmine red, scarlet red, red, color, etc. We can recognize here a foundational relation between what we can call a first, or straightforward, intention directed at the individual, and a second, or idealizing, intention directed at the species. On the basis of this latter intention further levels of generality can be built. Idealization and generalization are double intentions that maintain the material content. Accordingly, the intentional structure is comparable to the relation in medieval philosophy between phantasmata and first intentions.

(ii) Formalization is the process through which are intended formal categories, that is, categories that are devoid of any material content. Pure forms include categories such as object in general, something, subject, predicate, conjunction, disjunction, genus, species, etc. Formal categories can be ontological or apophantic; in both cases, according to Husserl, they can be intended and cognized thanks to a kind of abstraction from all the material content, or an abstracting operation that isolates the form by considering it as the form of all possible content, but not of any specific or concrete content (see Husserl 1969, pp. 48-49; 1983, pp. 26-27). The formal category object in general can be filled by anything that can be taken as objectual being. The category subject can be filled by any concept that can grammatically 
function as a subject of a judgment, etc. In this case too, we have a double intentional structure, for the abstracting intention directed at the form is grounded in the straightforward intention directed at concrete individuals. There is a complex process of abstraction in which the individual is co-intended while the form is abstracted. This can accordingly be considered analogous to the relation between first and second intentions.

\section{Action and Emotion}

Acts with a double intentional structure can be identified not only in the sphere of cognition, but also in that of emotion, volition, and action. Notably, double intentionality also characterizes the sharing of these kinds of experience with other persons. In the following, we briefly introduce some of the issues in these domains that can be fruitfully addressed by identifying a double intentional structure.

\subsection{Means, Ways, and Ends in Action}

\subsubsection{Medieval Approaches to Intention and Action}

Thomas Aquinas represents a clear example of a medieval account of double intentionality for the theory of action (Müller 2018). He devotes an entire chapter of the Summa theologiae to practical intentions (ST I-II, q. 12), where he holds that the term intentio is properly applied to mental acts by means of which we want to do something-that is, acts of the power of the human will-rather than cognitive acts, such as perceptions or understandings. This captures well the way in which we use the term intention in ordinary language today. Aquinas's conception of action involves two main elements: (i) the end for the sake of which a person acts - a person must want something to accomplish it and has reasons to strive for it; (ii) the means she takes to reach the intended end - she needs to deliberate about and take the proper steps to arrive at what she desires. Aquinas thinks that there must therefore be two intentions involved in an action. ${ }^{21}$

Does this mean that intentional action requires two mental acts? Or are the intention directed at the ultimate end, which Aquinas also calls prima intentio, ${ }^{22}$ and the intention directed at the intermediary ends part of one and the same mental act? He conceives of these intentions as

\footnotetext{
${ }^{21}$ ST I-II, q. 12, art. 3, co. (Thomas Aquinas 1891, p. 95b): "For intention is not only of the ultimate end, as has been said, but also of an intermediary end. Now one intends at the same time, both the proximate and the last end; as the preparation of medicine and health.".

22 ST I-II, q. 1, art. 6, ad 3 (Thomas Aquinas 1891, p. 14b); ST II-II, q. 83 , art. 13 , co. (1897, p. 206a).
}

teleologically interrelated: the ultimate end is the reason for performing the intermediate actions, and thus the intermediate goals are subordinated to the ultimate end. Accordingly, both the intermediate goals and the ultimate ends are intended in one and the same act of intention.

Aquinas speaks of an intention directed at two ends as an act of the human will. But his theory of action is also closely connected with the moral value of an intention from an ethical point of view. ${ }^{23}$ The question for medieval theologians like Aquinas is whether the intention, as an act of the will alone, is morally qualifiable or whether the circumstances of such an intention, such as the time and the place in which an action takes place, should also be counted as morally good or bad (ST I-II, q. 7). Every human action is accompanied by particular circumstances, and although they are not the action itself, they are related to the action and "touch" it, some of them more than others.

The question of what belongs to the circumstances of an act and what does not is crucial for John Duns Scotus and William Ockham with regard to the individuation of acts of the will. Both agree with Aquinas on the double intentionality of intentions in human actions. Consequently, they consider "being good" and "being bad" to be intrinsic properties of acts of willing. As Sonja Schierbaum shows in her contribution to this issue, Scotus's and Ockham's conceptions of action differ insofar as Scotus considers also the particular embodied actions resulting from an act of the will to have an intrinsic moral quality, whereas Ockham thinks that only interior acts of willing are intrinsically good or bad. On Ockham's account, all circumstances, including the end and the judgment of right reason, are partial objects of these acts.

\subsubsection{Goal-Orientedness and Execution in the Phenomenology of Action}

In phenomenological theories of action, double intentionality helps to clarify both how goal-oriented action arises and how intention and execution are related. As to the genesis of action, the general idea is that we should not analyze goal-directed actions in terms of behavior plus intention, but rather consider how the very intention to reach a goal is shaped on the basis of an instinctual kind of agency that is intentional in the broad sense of indeterminate directedness (Husserl 1989, 2020b; Merleau-Ponty 1963). ${ }^{24}$ The formation of a goal-directed intention presupposes an attentional

\footnotetext{
${ }^{23}$ As Müller (2018) argues, this does not prevent us from conceptually distinguishing practical intentionality from the ethical implications of the theory of action.

${ }^{24}$ This kind of pre-voluntary agency can be considered to correspond to behavior, if the latter is not reduced to the mere conception of stimulus/response, but rather is considered intentional in the broad sense of having some kind of open directedness. See Merleau-Ponty (1963).
} 
turn, which makes explicit and determines the open tending-toward as a being-directed at a goal or an object (see Summa and Mertens 2018). Accordingly, double intentionality makes up the structure of acting to the extent that every intention explicitly directed at a goal presupposes and takes up within itself an implicit instinctual intention as a tendingtoward (Husserl 2020b, pp. 67-68, 87-88, 99-100; cf. Spano 2021).

The relation between intending and executing is tied to this dynamic of shaping explicit intentions out of an indeterminate tending-toward. This structure of the relation between intention and execution holds for both straightforward actions (i.e., actions that are not composed of other actions, but rather occur in one go, like raising one's hand to grasp a cigar) and for complex actions (which are instead composed of partial actions, or Teilhandlungen, like buying a cake for the coffee break) (Husserl 2020b, pp. 6-7). Only in the latter case can we properly speak of a means-end relation: we want to buy the cake, and to this end we have to stand up, take our wallet, and go to the bakery before it closes. Yet in both cases we can speak of a relation between the aim of the action and the ways (Wege) of accomplishing it, mainly consisting in a bodily executive "doing" (Tun), which is intentional in a broad sense (Husserl 2020b, pp. 38-39). Thus, in both straightforward and complex actions, there is an interweaving of two intentions: one directed at the goal that is to be reached, and another directed at the ways (and possibly the means).

The articulation of intending and executing through partial and total intentions was reformulated with explicit reference to the paradigm of double intentionality by Hans Reiner (1927), who focuses on the relation between total unitary action and its partial moments (see Erhard 2019). What the action of buying the cake explicitly intends is something that transcends the action itself, for example, possessing the cake in order to be able to share it with others at a party or to enjoy it during the coffee break. But in another sense, we can say that when we intend to eat cake, this also involves intending to go to the bakery and not, for example, intending to bike home right away. If we intended to bike home instead of going to the bakery, and still claimed that the aim of our voluntary action was to buy a cake at the bakery, then there would clearly be something wrong with coordinating the two intentionalities: the intention directed at the end and the intention directed at the ways or the means for executing the action are not mutually fitted. In complex actions, double intentionality is tied to the moment of resolution (Entschluss), which expresses the willing of the total action. Here the genesis of action also plays a role, for the willing, which is rooted in a pre-voluntary and open drive, is what gives unity to the total action.

\subsection{Emotional Experience}

\subsubsection{The Formal Object: Medieval and Contemporary Approaches}

The term intentio plays a crucial role in the medieval theory of emotions. Take the famous example from Avicenna of the sheep that flees at the sight of a wolf. It seems clear that the sheep flees because it is afraid of the wolf. But how can we explain how the sheep's feeling of fear comes about? Avicenna holds that when the sheep sees a wolf, it receives not only the various sensible features of the wolf, but also what Avicenna calls ma'ân, rendered in the Latin West as intentiones: certain connotational attributes, in this case the dangerousness of the wolf (see Hasse 2000). Questions as to what exactly such a connotational attribute might be and how it is transmitted from the wolf and received by the sheep were extensively debated in the Middle Ages (Perler 2012; Oelze 2018). Regardless of what exactly the ontological status of an intention like that of dangerousness is and how the underlying psychological mechanism is to be understood, such an intentio is supposed to provide an explanation of the emotion of fear.

A common way of explaining particular emotions (e.g., fear, anger, joy) is to say that each emotion has a formal object on account of which an emotion is cognitively evaluable; for example, fear is directed at an object which is evaluated as bad or threatening, whereas joy is directed at an object which is evaluated as good or useful. Emotions can thus be classified and investigated according to their formal objects (Perler 2018). However, in Aquinas feelings or emotions are not considered as always having just one simple formal object. Again, we can see a double intentionality at work, namely, with respect to a double object underlying the emotional response. Aquinas holds that emotions such as joy and sorrow can be conceived as being directed at a simple object when the appetitive power simply adheres to something good, as when we enjoy drinking wine. Love and hate typically have a complex object at which they are directed: in loving someone we wish them something good, and both the beloved persons and what we wish them are considered under the aspect of good, while in hating someone we wish them something bad, and both the hated persons and what we wish them are considered under the aspect of evil. Anger, on the other hand, is directed both at something bad, namely, the actions of someone who has harmed us, and at something good, namely, the vengeance we seek (ST I-II, q. 46, art. 2). 
The formal object approach has also inspired modern philosophers, notably raising the following two questions ${ }^{25}$ : (i) How is it possible to conceive of the relation between particular objects and the formal object of an emotion? (ii) How is it possible to assess emotions on account of their formal object? In their contribution to this issue, Tricia Magalotti and Uriah Kriegel take up these questions by elaborating on the formal object approach in order to account for the epistemology of emotions. Regarding the first question, they propose to conceive of emotions as having both an intentional object, which an emotion represents, and an intentional mode or attitude, which frames how the object is represented in an emotional state. Regarding the second question, they show that emotions, unlike belief, do not have truth as their formal object; however, they still are epistemically assessable insofar as they are "constitutively evidence-responsive".

\subsubsection{Indirect Emotions and Shared Emotions as Phenomenological Case Studies}

Brentano claims that every intentional act either is a representation or is grounded in a representation, arguing that emotional and volitional acts and judgments presuppose the representation of their object. ${ }^{26}$ To fear a wolf, and thus to grasp it as something dangerous and to be avoided, requires that one have a representation of it. In 1874 Brentano had argued that all presentations are accompanied by emotions, but he later held that there are presentations which occur without an accompanying feeling (Brentano 1995, pp. 207-208, 215).

Brentano's approach to the foundational relation between representations on the one hand and emotional and volitional acts on the other was criticized by Husserl. The gist of the critique consists in the rejection of the assumptions that emotional and volitional acts are founded on acts of representation. Departing from Brentano's terminology, Husserl resorts instead to a distinction between objectivating and non-objectivating acts (see Melle 1990). He argues that the concept of representation needs to be disambiguated; in particular, we need to distinguish between the act and what Husserl calls the intentional matter of representation. While denying that non-objectivating acts are founded on the representational acts, Husserl argues that we should consider nonobjectivating acts as founded on the intentional matter of a

\footnotetext{
${ }^{25}$ See, notably, Kenny (1963), who makes explicit reference to Brentano and Aquinas, as well as de Sousa (1987), Goldie (2000), and Prinz (2004).

${ }^{26}$ Brentano (1995) subsumes emotional and volitional states equally under the third class of psychic phenomena of love and hate or sentimental relation (Gemütsbeziehung). He cites Aristotle and Aquinas in support of this view.
}

representation, that is, on the object of a representation in its specific mode of appearance (Husserl 2001b, pp. 128-129).

Accordingly, for Husserl the paradigm of double intentionality understood on the basis of the relation to a formal object seems not to be applicable to the analysis of direct emotions. My fear of a wolf is directed at the wolf immediately experienced as dangerous; what this act presupposes is thus the givenness of the wolf as dangerous. The fear of the wolf, on Husserl's description, does not involve a directedness to a formal object dangerousness but consists in a directedness to the particular object that is a wolf in a specific mode of appearance as dangerous. The wolf is thus the only object in Husserl's understanding of the fear of the wolf. However, if we extend the remarks on double intentionality in the directedness to objects and concepts (see Sect. 3.2. above), a parallel with the theory of the formal object—and therefore also with the epistemic approach proposed by Magalotti and Kriegel-may be consistent with Husserl's view on emotions. Just as when we see a red object we can focus our attention on the red in specie in the same way, when we perceive a dangerous object we can turn our attention to the dangerousness in specie. In both cases, we would perform an "ideational abstraction" (ideierende Abstraktion), which entails a relation to both the particular object and the general concept (Husserl 2001a, pp. 145, 308-309).

The paradigm of double intentionality plays a more substantial role when it comes to Husserl's phenomenology of indirect emotions such as approval (Billigung) (Husserl 2020a, pp. 261-319). For instance, if we approve of our anger at someone, we have an emotional intentionality that is directed at another emotion, which in turn has a direct object. The intentionality of approval has a double character to the extent that it involves a stance-which is not itself cognitive but emotional-regarding one's own emotions, and thus also encompasses the intentional structure of the original direct emotions.

Emotional acts are in most contexts characterized by their intersubjective and social character. A closer assessment of how the paradigm of double intentionality can be fruitfully applied to the analysis of specifically intersubjective and social emotions, such as shame, pride, envy, etc., is certainly desirable. At least implicitly, several studies suggest that these emotions have a double intentional structure. ${ }^{27}$ Another issue, partially related to this one, concerns collective emotions. In this regard, as Alessandro Salice emphasizes in his contribution, a problem connected with the broader issue of the relation between object-consciousness and selfconsciousness arises (see Sect. 2 above). Salice argues that,

\footnotetext{
27 See, e.g., Fuchs (2002), Rinofner-Kreidl (2009, 2014), Salice and Montes Sánchez (2016), and Zahavi (2014, 2020).
} 
in collective emotions, we are pre-reflectively self-aware in a way that differs from individual experiences. Pre-reflective self-awareness in the experience of shared emotions is articulated in a more complex way insofar as it includes the awareness of ourselves not only as individuals, but also as we, that is, as members of a group. Accordingly, a phenomenological theory of collective emotions should be based on the double intentional relation between our self-awareness as group members and our shared object-directedness.

\section{Concluding Remarks}

This introduction has brought to the fore the plurality of facets of the theoretical models of double intentionality. This plurality is due partly to the scope of the various models and partly to their historical and theoretical embeddedness. The individual domains of inquiry that require an analysis of double intentionality, as well as the different theoretical approaches, display some shared structures. In some respects, however, individual theories remain constitutively distinct and irreducible to a common denominator. A synoptic perspective on double intentionality through the lens of phenomenology and medieval philosophy has the merit of bringing to light precisely this plurality of research fields while providing a preliminary systematization of the theoretical models of double intentionality and of the fields to which they apply. It remains an exciting task for future research to delve into the specifics of the structure of double intentionality in each area, to probe the validity of individual theories of double intentionality, to develop new ones, and to assess the impact of these theories for inquiry into experience and cognition.

Acknowledgements We would like to thank the editors of Topoi, our contributors, and reviewers for their smooth collaboration. We are grateful to Lukas Beckmann and Nargis Silva for their support in the editing of some of the manuscripts. Specials thanks to Jörn Müller, Karl Mertens, and Ian Drummond for helpful comments on earlier versions of this paper.

Funding Open Access funding enabled and organized by Projekt DEAL. This work is part of the project Modes of Intentionality: A Historical-Systematic Analysis (Dep. of Philosophy) funded by the University of Würzburg.

Open Access This article is licensed under a Creative Commons Attribution 4.0 International License, which permits use, sharing, adaptation, distribution and reproduction in any medium or format, as long as you give appropriate credit to the original author(s) and the source, provide a link to the Creative Commons licence, and indicate if changes were made. The images or other third party material in this article are included in the article's Creative Commons licence, unless indicated otherwise in a credit line to the material. If material is not included in the article's Creative Commons licence and your intended use is not permitted by statutory regulation or exceeds the permitted use, you will need to obtain permission directly from the copyright holder. To view a copy of this licence, visit http://creativecommons.org/licenses/by/4.0/.

\section{References}

Amerini F (2011a) Intention, primary and secondary. In: Lagerlund H (ed) Encyclopedia of medieval philosophy: philosophy between 500 and 1500. Springer, Dordrecht, pp 555-558

Amerini F (2011b) Intentionality. In: Lagerlund H (ed) Encyclopedia of medieval philosophy: philosophy between 500 and 1500 . Springer, Dordrecht, pp 558-564

Anisi A, Friedman RL, Pelletier J, Sorokina M (eds) (2020) Theories of mental being in the later Middle Ages. Recherches de théologie et philosophie médiévales $87(2)$

Aristotle (1984) The complete works of Aristotle: the revised Oxford translation (ed Barnes J). Princeton University Press, Princeton

Augustine (1990) Confessionum libri XIII (ed Verheijen L). Corpus Christianorum Series Latina vol. 27. Brepols, Turnhout

Avicenna (1952) Kitâb al-Shifâ': al-Madkhal (ed el-Khodeiri M, Anawati G, el-Ahwani F). Organisation Générale des Imprimeries Gouvernementales, Cairo

Avicenna (2005) Kitâb al-Shifâ': al-Ilâhiyyât (ed Marmura ME) Brigham Young University Press, Provo

Bernet R (1985) Einleitung. In: Bernet R (ed) Edmund Husserl: Texte zur Phänomenologie des inneren Zeitbewusstseins (1893-1917), Text nach Husserliana X. Meiner, Hamburg, pp xi-lxvii

Binder T (2019) Franz Brentano und sein philosophischer Nachlass. De Gruyter, Berlin

Brentano F (1867) Geschichte der kirchlichen Wissenschaften. In: Möhler JA, Gams PB (eds) Kirchengeschichte, Bd. 2: Zweiter Zeitraum. Das Mittelalter. Manz, Regensburg, pp 526-584

Brentano F (1995) Psychology from an empirical standpoint (ed McAlister LL, trans Rancurello AC et al). Routledge, London

Brower-Toland S (2012) Medieval approaches to consciousness: Ockham and Chatton. Philosophers' Imprint 12(17):1-29

Brower-Toland S (2013) Olivi on consciousness and self-knowledge: the phenomenology, metaphysics, and epistemology of the mind's reflexivity. Oxford Stud Med Philosophy 1:136-171

Brower-Toland S (2014) William Ockham on the scope and limits of consciousness. Vivarium 52:197-219

Cesalli L, Taieb H (2018) Brentano and medieval ontology. Brentano Studien 16:335-364

Cory TS (2012) Diachronically unified consciousness in Augustine and Aquinas. Vivarium 50:354-381

Cory TS (2013) What is an intellectual "turn"? The Liber de causis, Avicenna, and Aquinas's turn to phantasms. Tópicos Revista De Filosofía 45:129-162

Crane T (1998) Intentionality as the mark of the mental. In: O'Hear A (ed) Contemporary issues in the philosophy of mind. Cambridge University Press, Cambridge, pp 228-251

Cross R (2014) Duns Scotus's theory of cognition. Oxford University Press, Oxford

De Rijk L-M (2005) A study of the medieval intentionality debate up to ca. 1350. In: de Rijk L-M (ed) Giraldus Odonis O.F.M., Opera philosophica, vol. II: De intentionibus. Brill, Leiden, pp 19-376

De Santis D (2021) Husserl and the a priori: phenomenology and rationality. Springer, Cham

De Sousa R (1987) The rationality of emotions. MIT Press, Cambridge, Mass.

De Warren N (2009) Husserl and the promise of time: subjectivity in transcendental phenomenology. Cambridge University Press, Cambridge

De Warren N (2016) Augustine and Husserl on time and memory. Quaestiones Disputatae 7(1):7-46 
Dewalque A (2014) Intentionnalité in obliquo. Bulletin d'analyse phénoménologique 10(6):40-84

Dewan L (1981) "Obiectum": notes on the invention of a word. Archives d'histoire doctrinale et littéraire du Moyen-Âge 56:37-96

Doyle JP (2009) Hervaeus Natalis on intentionality: its direction and some aftermath. In: Brown SF, Dewender T, Kobusch T (eds) Philosophical debates at Paris in the early fourteenth century. Brill, Leiden, pp 261-283

Durand of Saint-Pourçain (1962) Le "Quaestiones de libero arbitrio" di Durando da S. Porciano (ed Stella PT). Salesianum 24(3):450-524

Eardley P (2021) Medieval theories of conscience. In Zalta EN (ed) Stanford encyclopedia of philosophy. https://plato.stanford.edu/ entries/conscience-medieval/

Erhard C (2019) Unifying agency: reconsidering Hans Reiner's phenomenology of activity. Husserl Stud 35:1-25

Frank M (2015) Präreflexives Selbstbewusstsein: Vier Vorlesungen. Reclam, Stuttgart

Fuchs T (2002) Shame, guilt, and the body: a phenomenological view. J Phenomenol Psychol 33(2):223-243

Goldie P (2000) The emotions: a philosophical explanation. Clarendon Press, Oxford

Gurwitsch A (1966) Studies in phenomenology and psychology. Northwestern University Press, Evanston

Gyekye K (1971) The terms "prima intentio" and "secunda intentio" in Arabic logic. Speculum 46:32-38

Hartman P (2021) Durand of St.-Pourçain on reflex acts and state consciousness. Vivarium 59:215-240

Hartmann N (1985) Zur Grundlegung der Ontologie. De Gruyter, Berlin

Hasse DN (2000) Avicenna's De anima in the Latin West: the formation of a Peripatetic philosophy of the soul 1160-1300. Warburg Institute, London

Hasse DN (ed) (2021) Arabic and Latin Glossary. https://algloss.de. dariah.eu

Hedwig K (1978) Der scholastische Kontext des Intentionalen bei Brentano. In: Chisholm RM, Haller R (eds) Die Philosophie Brentanos. Rodopi, Amsterdam, pp 67-82

Henry M (1973) The essence of manifestation. Nijhoff, The Hague

Henry of Ghent (1518) Quodlibeta. Badius, Paris

Hervaeus Natalis (2008) On second intentions (ed and trans Doyle JP). Marquette University Press, Milwaukee

Hossack K (2002) Self-knowledge and consciousness. Proc Aristot Soc 102:163-181

Husserl E (1960) Cartesian meditations (trans Cairns D). Nijhoff, The Hague

Husserl E (1969) Formal and transcendental logic (trans Cairns D). Nijhoff, The Hague

Husserl E (1970) The crisis of European sciences and transcendental phenomenology: an introduction to phenomenological philosophy (trans Carr D). Northwestern University Press, Evanston

Husserl E (1983) Ideas pertaining to a pure phenomenology and to a phenomenological philosophy, first book: general introduction to a pure phenomenology (trans Kersten F). Kluwer, Dordrecht

Husserl E (1989) Ideas pertaining to a pure phenomenology and to a phenomenological philosophy, second book: studies in the phenomenology of constitution (trans Rojcewicz R, Schuwer A). Kluwer, Dordrecht

Husserl E (1991) On the phenomenology of the consciousness of internal time (1893-1917) (trans Brough JB). Kluwer, Dordrecht

Husserl E (2001a) Logical investigations, first volume: prolegomena to pure logic, investigations I and II (trans Findlay JN). London, Routledge

Husserl E (2001b) Logical investigations, second volume: investigations III, IV, V, VI (trans Findlay JN). Routledge, London
Husserl E (2006) The basic problems of phenomenology: from the lectures, winter semester, 1910-1911 (trans Hart J, Farin I). Springer, Dordrecht

Husserl E (2020a) Studien zur Struktur des Bewusstseins, Teilband II: Gefühl und Wert, Texte aus dem Nachlass (1896-1925). Springer, Cham

Husserl E (2020b) Studien zur Struktur des Bewusstseins, Teilband III: Wille und Handlung, Texte aus dem Nachlass (1902-1934). Springer, Cham

Husserl E (2005) Phantasy, image consciousness, and memory (18981925) (trans Brough JB). Springer, Dordrecht

Jacob P (2014) Intentionality. In: Zalta EN (ed) Stanford encyclopedia of philosophy. https://plato.stanford.edu/entries/intentionality/

Jacquette D (2004) Brentano's concept of intentionality. In: Jacquette D (ed) The Cambridge companion to Brentano. Cambridge University Press, Cambridge, pp 98-130

Jansen J (2017) Eidetik. In: Luft S, Wehrle M (eds) Husserl handbook. Metzler, Stuttgart, pp 142-149

Kenny A (1963) Action, emotion and will. Routledge, London

King P (2010) Mediaeval intentionality and pseudo-intentionality. Quaestio 10:25-44

Klein M (2019) Philosophie des Geistes im Spätmittelalter: Intellekt, Materie und Intentionalität bei Johannes Buridan. Brill, Leiden

Klima G (2013) Three myths of intentionality vs. some medieval philosophers. Int J Philos Stud 21:359-376

Klima G (2015) Introduction. In: Klima G (ed) Intentionality, cognition, and mental representation in medieval philosophy. Forham University Press, New York, pp 1-8

Knebel SK (2009) Phänomenologen horchen auf. Der Taufschein der "Intentionalität" ist jetzt ediert. Freiburger Zeitschrift für Philosophie und Theologie 56:257-264

Knebel SK (1998) Subjekt/Objekt; subjektiv/objektiv. In: Ritter J, Gründer K, Gabriel G (eds) Historisches Wörterbuch der Philosophie. Vol. 10. Schwabe, Basel, pp 401-407, 410-413

Kobusch T (1987) Objekt. In: Ritter J, Gründer K, Gabriel G (eds) Historisches Wörterbuch der Philosophie. Vol. 6, Schwabe, Basel, pp 1026-1030

Kortooms T (2002) Phenomenology of time: Edmund Husserl's analysis of time-consciousness. Kluwer, Dordrecht

Kriegel U (2016) Brentano's dual-framing theory of consciousness. Philos Phenomenol Res 97(1):79-98

Lohmar D (2008) Kategoriale Anschauung: VI. Logische Untersuchung, §§ 40-66. In: Meyer V (ed) Edmund Husserl: Logische Untersuchungen. De Gruyter, Berlin, pp 209-237

Lohmar D (1998) Erfahrung und kategoriales Denken: Hume, Kant und Husserl über vorprädikative Erfahrung und prädikative Erkenntnis. Kluwer, Dordrecht

Lohmar D (2005) Die phänomenologische Methode der Wesensschau und ihre Präzisierung als eidetische Variation. Phänomenologische Forschungen 2005(1):65-91

Marbach E (1993) Mental representation and consciousness. Springer, Dordrecht

Marchesi A (2019) Brentanian inner consciousness and the infinite regress problem. Dialectica 73(1-2):129-147

Marras A (1977) Scholastic roots of Brentano's conception of intentionality. In: McAlister L (ed) The philosophy of Brentano. Humanities Press, London, pp 128-139

Mc Donnell C (2015) Understanding and assessing "Brentano's Thesis" in light of his modification of the scholastic concept of intentionality. Brentano Studien 13:153-182

Melle U (1990) Objektivierende und nicht-objektivierende Akte. In: Ijsseling S (ed) Husserl-Ausgabe und Husserl-Forschung. Kluwer, Dordrecht, pp 35-49

Menn S (2012) Self-motion and reflection: Hermias and Proclus on the harmony of Plato and Aristotle on the soul. In: Wilberding J, 
Horn C (eds) Neoplatonism and the philosophy of nature. Oxford University Press, Oxford, pp 44-67

Merleau-Ponty M (1963) The structure of behavior (trans Fisher AL). Beacon Press, Boston

Merleau-Ponty M (2005) Phenomenology of perception (trans Smith C). Routledge, London

Michon C (2007) "Ego intelligo (lapidem)": deux conceptions de la réflexion au Moyen Âge. In: Boulnois O (ed) Généalogies du sujet. Vrin, Paris, pp 113-150

Moran D (2013) Intentionality: some lessons from the history of the problem from Brentano to the present. Int J Philos Stud 21(3):317-358

Müller J (2015) Memory in medieval philosophy. In: Nikulin D (ed) Memory: a history. Oxford University Press, Oxford, pp 92-124

Müller J, Summa M (2018) Modes of intentionality: phenomenologi$\mathrm{cal}$ and medieval perspectives. Phaenomenologische Forschungen 2018(2):5-24

Müller J (2018) A medieval view of practical intentionality: intentio in Aquinas' psychology of action. Phänomenologische Forschungen 2018(2):155-175

Nikulin D (2015) Memory in ancient philosophy. In: Nikulin D (ed) Memory: a history. Oxford University Press, Oxford, pp 35-84

Oelze A (2018) Animal rationality: later medieval theories 1250-1350. Brill, Leiden

Oschman NA (2018) The constitution of the intellect and the Fārābīan doctrine of first and second intention. Phänomenologische Forschungen 2018(2):45-59

Pasnau R (2002) Thomas Aquinas on human nature: a philosophical study of Summa theologiae Ia 75-89. Cambridge University Press, Cambridge

Perler D (2004) Theorien der Intentionalität im Mittelalter, 2nd edn. Klostermann, Frankfurt am Main

Perler D (2012) Why is the sheep afraid of the wolf? Medieval debates on animal passions. In: Shapiro L, Pickavé M (eds) Emotion and cognitive life in medieval and early modern philosophy. Oxford University Press, Oxford, pp 32-52

Perler D (2018) Feelings transformed: philosophical theories of the emotions 1270-1670. Oxford University Press, Oxford

Perler D (2020) Eine Person sein: Philosophische Debatten im Spätmittelalter. Klostermann, Frankfurt am Main

Perler D, Schierbaum S (2014) Einleitung. In: Perler D, Schierbaum S (eds) Selbstbezug und Selbstwissen: Texte zu einer mittelalterlichen Debatte. Klostermann, Frankfurt am Main, pp 11-68

Peter John Olivi (1926) Quaestiones in secundum librum Sententiarum (ed Jansen P). Vol. 3. Quaracchi: Collegium St. Bonaventure

Pinborg J (1974) Zum Begriff der "intentio secunda": Radulphus Brito, Hervaeus Natalis und Petrus Aureoli in Diskussion. CIMAGL 13:49-59

Pini G (2002) Logic and categories in Duns Scotus. Brill, Leiden

Prinz JJ (2004) Gut reactions: a perceptual theory of emotion. Oxford University Press, Oxford

Putallaz F-X (1991) Le sens de la réflexion chez Thomas d'Aquin. Vrin, Paris

Recanati F (2000) Oratio obliqua, oratio recta. MIT Press, Cambridge, Mass.

Reiner H (1927) Freiheit, Wollen und Aktivität: Phänomenologische Untersuchungen in Richtung auf das Problem der Willensfreiheit. Niemeyer, Halle

Rinofner-Kreidl S (2009) Scham und Schuld: Zur Phänomenologie selbstbezüglicher Gefühle. Phänomenologische Forschungen 2009(1):137-173

Rinofner-Kreidl S (2014) Neid und Ressentiment: Zur Phänomenologie negativer sozialer Gefühle. In: Müller J, Mertens K (eds) Die Dimension des Sozialen: Neue Philosophische Zugänge zu Fühlen, Wollen und Handeln. De Gruyter, Berlin, pp 103-126
Rollinger RD (2010) Philosophy of language and other matters in the work of Anton Marty. Rodopi, Amsterdam

Rollinger RD (2011) Brentano's Psychology from an Empirical Standpoint: its background and conception. In: Tănăsescu I (ed) Franz Brentano's metaphysics and psychology. Zeta Books, Bucharest

Rosenthal DM (1997) A theory of consciousness. In: Block N, Flanagan $\mathrm{O}$, Guzeldere $\mathrm{G}$ (eds) The nature of consciousness. MIT Press, Cambridge, Mass., pp 729-753

Runggaldier E (1989) On the scholastic or aristotelian roots of "intentionality" in Brentano. Topoi 8:97-103

Salice A, Montes Sánchez A (2016) Pride, shame, and group identification. Front Psychol. https://doi.org/10.3389/fpsyg.2016.00557

Sartre J-P (1956) Being and nothingness: an essay on phenomenological ontology (trans Barnes HE). Philosophical Library, New York

Sartre J-P (2004) The transcendence of the ego: a sketch for a phenomenological description (trans Brown A). Routledge, London

Schreiber C (2021) Was versteht Brentano in der Intentionalitätspassage unter einem Objekt eines psychischen Phänomens? In: Antonelli M, Binder T (eds) The philosophy of Brentano. Brill, Leiden, pp 250-262

Siewert C (2017) Consciousness and intentionality. In: Zalta EN (ed) Stanford encyclopedia of philosophy. https://plato.stanford.edu/ archives/spr2017/entries/consciousness-intentionality/

Simons P (1995) Introduction to the second edition. In: McAlister LL (ed) Franz Brentano: Psychology from an Empirical Standpoint. Routledge, London, pp xiii-xx

Soldati G (2017) Brentano on self-knowledge. In: Kriegel U (ed) The Routledge handbook of Franz Brentano and the Brentano School. Routledge, London, pp 124-129

Sowa R (2007) Wesen und Wesensgesetze in der deskriptiven Eidetik Husserls. Phänomenologische Forschungen 2007(1):5-37

Sowa R (2021) Eidetic description in Husserl's phenomenology. In: Jacobs H (ed) The Husserlian mind. Routledge, London, pp $100-117$

Spano N (2021) The genesis of action in Husserl's Studien zur Struktur des Bewusstseins. J Br Soc Phenomenol. https://doi.org/10.1080/ 00071773.2021.1909426

Street T, Germann N (2013) Arabic and Islamic philosophy of language and logic. In: Zalta EN (ed) Stanford encyclopedia of philosophy. https://plato.stanford.edu/entries/arabic-islamic-language/

Summa M (2014) Spatio-temporal intertwining: Husserl's transcendental aesthetic. Springer, Dordrecht

Summa M, Mertens K (2018) On the role of attention and ascription in the formation of intentions within behavior. Phänomenologische Forschungen 2018(2):177-196

Taieb H (2018) Relational intentionality: Brentano and the Aristotelian tradition. Springer, Cham

Textor M (2006) Brentano (and some Neo-Brentanians) on inner consciousness. Dialectica 60(4):411-432

Thomas Aquinas (1889) Pars prima Summae theologiae, qq. 50-119. In: Commissio Leonina (ed) Opera omnia. Vol. 5. Ex Typographia Polyglotta S. C. de Propaganda Fide, Rome

Thomas Aquinas (1891) Prima secundae Summae theologiae, qq. 1-70. In: Commissio Leonina (ed) Opera omnia. Vol. 6. Ex Typographia Polyglotta S. C. de Propaganda Fide, Rome

Thomas Aquinas (1897) Secunda secundae Summae theologiae, qq. 57-122. In: Commissio Leonina (ed) Opera omnia. Vol. 9. Ex Typographia Polyglotta S. C. de Propaganda Fide, Rome

Thomasson AL (2002) After Brentano: a one-level theory of consciousness. Eur J Philos 8(2):190-209

Walter Chatton (1989) Reportatio et lectura super Sententias: collatio ad librum primum et prologus (ed Wey JC). PIMS, Toronto

Werle JM (1982) Zur Edition der Vorlesungen Franz Brentanos über Geschichte der Philosophie. Phänomenologische Forschungen, pp 178-187 
Wiesing L (2020) Ich für mich: Phänomenologie des Selbstbewusstseins. Suhrkamp, Frankfurt am Main

William of Ockham (1980) Quodlibeta septem. In: Gál G et al (ed) Opera Philosophica et Theologica. Vol. 9. Franciscan Institute, St. Bonaventure, $\mathrm{NY}$

Yrjönsuuri M (2007) The structure of self-consciousness: a fourteenthcentury debate. In: Heinämaa S, Lähteenmäki V, Remes P (eds) Consciousness: from perception to reflection in the history of philosophy. Springer, Dordrecht, pp 141-152

Zahavi D (1998) Brentano and Husserl on self-awareness. Études Phénoménologiques 27(28):127-168

Zahavi D (1999) Self-awareness and alterity: a phenomenological investigation. Northwestern University Press, Evanston

Zahavi D (2002) The three concepts of consciousness in the Logische Untersuchungen. Husserl Stud 18(1):51-64
Zahavi D (2004) Back to Brentano? J Conscious Stud 11(10-11):66-87

Zahavi D (2014) Self and other: exploring subjectivity, empathy, and shame. Oxford University Press, Oxford

Zahavi D (2020) Shame. In: Szanto T, Landweer H (eds) The Routledge handbook of phenomenology of emotions. Routledge, London, pp 349-357

Zupko J (2015) On the several senses of "intentio" in Buridan. In: Klima $\mathrm{G}$ (ed) Intentionality, cognition, and mental representation in medieval philosophy. Fordham University Press, New York, pp 251-272

Publisher's Note Springer Nature remains neutral with regard to jurisdictional claims in published maps and institutional affiliations. 